\title{
Serious Games at the service of student's integration into the work sector: Case of computer science engineering students
}

\author{
Zineb Sabri ${ }^{1,}{ }^{*}$, Aniss Moumen ${ }^{2}$, and Youssef Fakhri ${ }^{1}$ \\ ${ }^{1}$ Laboratory of Computer Science, Ibn Tofaïl University, Kenitra, Morocco \\ ${ }^{2}$ National School of Applied Sciences, Ibn Tofaïl University, Kenitra, Morocco \\ ${ }^{3}$ Laboratory of Computer Science, Ibn Tofaïl University, Kenitra, Morocco
}

\begin{abstract}
Students develop a big commitment personally and invest financially to pursue their education and get the degree that opens many gateways for them, but what if the degrees don't match the skills required by most employers? As time has changed, employability is based on knowledge and several abilities such as soft skills, communication, leadership, creative and critical thinking. It is hard for universities to keep track of all these changes and, at the same time, the technological advancements, the hard facts and the skills of most of the disciplines. Our research aims to study the needs requested the most by employers. To achieve that, we started with a survey with some laureates and multiple interviews with different recruiters to identify their requirements. We can define the training students need to have before integrating the job market, ease their insertion, and make their integration successful.
\end{abstract}

\section{Introduction}

Since the 1990s, serious games had emerged in the research field, as we stated in our previous papers, especially the use of fun in the education field when we conducted an interesting and detailed literature review [1]. We collected and analyzed more than 224 papers from different research databases like Science Direct, Springer Link, Web of Science, IEEE Xplore Digital Library, Cairn and Scopus. Then, we followed the methodology of N7+1 (see Fig. 1) and NVivo, a qualitative data analysis software, to analyze our corpus set deeply. We got multiple results confirming the relationship between learning, education and games, starting with distribution charts to the frequency analysis and the comparative analysis of several reviews and results articles. Based on the outcomes concluded, we started studying the application of serious games in our context, making the student's insertion into the work sector much more accessible and filling the gaps detected when integrating the job market for the first time.

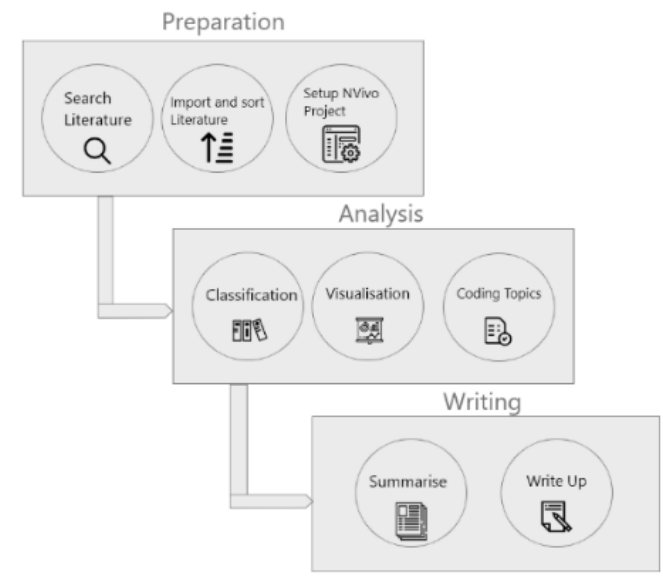

Fig. 1. N7+1 approach and steps.

\footnotetext{
$\overline{\text { *Corresponding author: zineb.sabri@uit.ac.ma }}$
} 
We implemented two games. One puts the player in different situations simulating him going for his first job interview, and he gets to play by the options to gain points and win or lose at the end. If the option chosen by the player is wrong, he gets to understand why due to the indications added in the game.
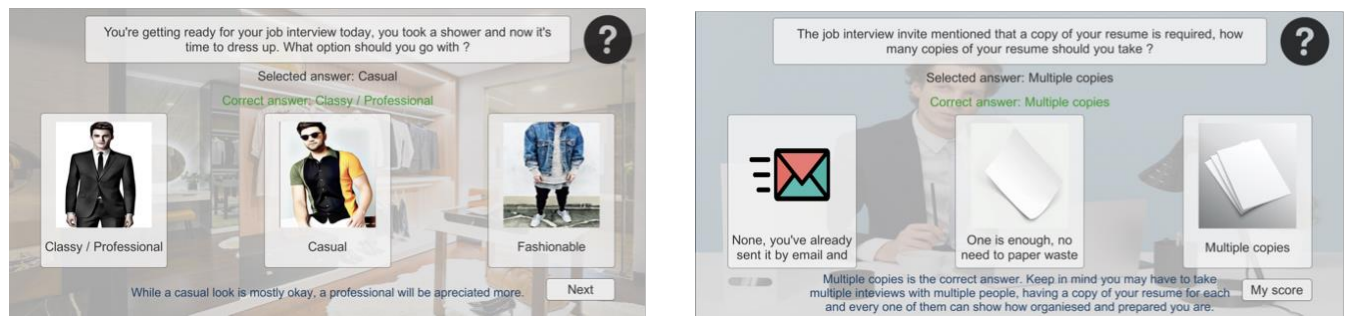

Fig. 2. Examples of the game quizzes.

The second one is a drag and drop game. While playing it, the student learns how to make a resume to understand the first steps towards the job market.
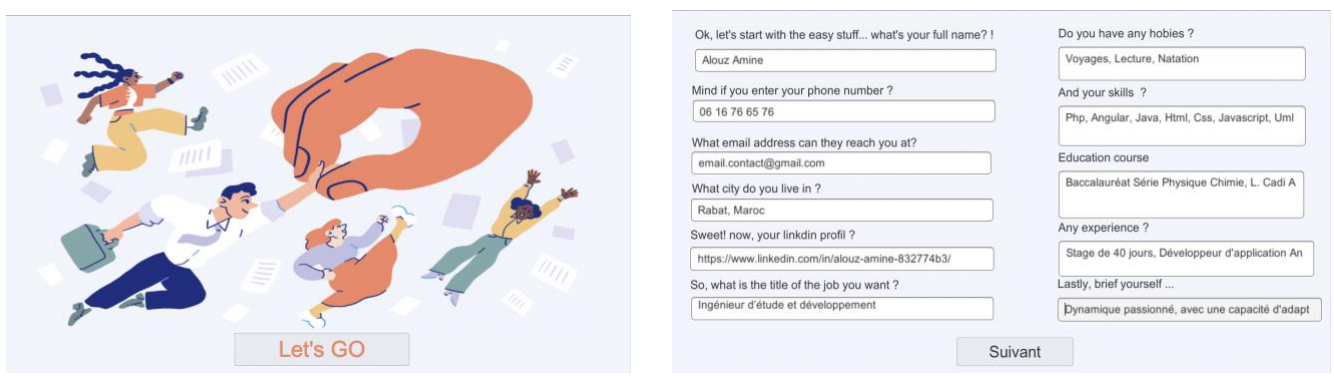

Fig. 3. Examples of the resume game.

In pursuing this demarche, we had to identify the skills and abilities required by recruiters to design a serious game intending to help the students get the right abilities entreatingly. We started with the computer science engineering laureates inside an international It company, and we will present the methodology followed in the next section.

\section{Methods}

Learning games are an effective method of instruction. Still, they need to focus on a particular outcome. We are linking the goals of a learning game directly to a successful insertion inside companies.

The game process design and development follow the steps mentioned in Fig. 4. The model is an adaptation of DesignBased Research (DBR) and the serious game's project by Marfisi-Schottman et al. [2].

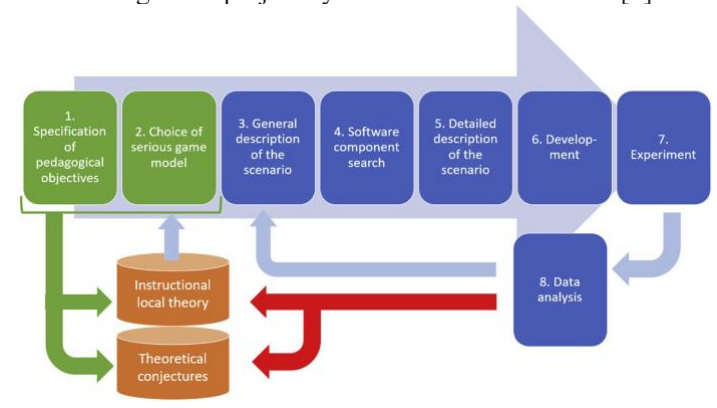

Fig. 4. Model of development and research process. 
Design-Based Research (DBR) is concerned with the practical application of learning theories. To define the first step of specification of pedagogical objectives, we had to identify the required training lacking students before their integration. We followed an exploratory method and qualitative method using questionnaire surveys and interviews to explore the experiences in the depth of both laureates and the recruiters.

\subsection{Exploratory Survey}

The first survey we created was dedicated to laureates who integrated an international IT company located in many cities in Morocco; our target sample is nearly sixty engineers freshly recruited after achieving their project graduation. Each one of them is from a different academic background, as we will see in the results section. We launched this survey inside the company under the theme: "Turn data into information and information into insight" while explaining that this is part of a big goal to help improve insertion into companies, allowing future laureates to have a better experience.

The survey is composed of three sections:

- Presentation: this section contains different questions about the name, email address, date of integration to have clear statistics about the responders.

- Integration: in this section, we asked the engineers about their first integration, did they pass training courses or not, the types of these mandatory training, were the sessions were on the e-learning platform or just the traditional form.

- Perspective: finally, we asked the ex-laureates their feedback about their integration experience and any suggestion or ideas to improve this process.

\subsection{The qualitative method}

In this step, we started by preparing two samples of the interview guide, one for decision-makers of recruiting inside the company, such as the director, the manager, the team leaders and human resources. The second one was for the exlaureates who integrated the company successfully.

We managed to achieve multiple interviews with the decision-makers of recruiting a new laureate or not. The table below displays some indicators of some interviewees, their positions in the company, academic background and seniority.

Table 1. Presentation of interviewees.

\begin{tabular}{|c|c|c|}
\hline $\begin{array}{c}\text { Company/ } \\
\text { School }\end{array}$ & Position & Experience \\
\hline $\begin{array}{c}\text { CGI / } \\
\text { ENSIAS }\end{array}$ & $\begin{array}{c}\text { Project Director / } \\
\text { Innovation and digital } \\
\text { transformation } \\
\text { specialist }\end{array}$ & $\begin{array}{c}\text { More than } \\
\text { ten years }\end{array}$ \\
\hline $\begin{array}{c}\text { CGI / } \\
\text { IIHEM }\end{array}$ & Project Manager & $\begin{array}{c}\text { five to ten } \\
\text { years }\end{array}$ \\
\hline $\begin{array}{c}\text { CGI / } \\
\text { Faculty of } \\
\text { Science ibn } \\
\text { Zohr }\end{array}$ & Team Leader & $\begin{array}{c}\text { three to five } \\
\text { years }\end{array}$ \\
\hline $\begin{array}{c}\text { CGI / } \\
\text { ENSA Safi }\end{array}$ & Software engineer & $\begin{array}{c}\text { two to three } \\
\text { years }\end{array}$ \\
\hline $\begin{array}{c}\text { CGI / } \\
\text { EST Sale }\end{array}$ & Software engineer & $\begin{array}{c}\text { two to three } \\
\text { years }\end{array}$ \\
\hline
\end{tabular}

The interview guide is composed of six parts:

- Presentation

- Introductive section.

- Centring section.

- Deepening section.

- Conclusion. 
Table 2. Interview guide's sections

\begin{tabular}{|c|c|}
\hline Phase & Goal \\
\hline Presentation & $\begin{array}{c}\text { Present the context of the } \\
\text { interview, interviewee's data } \\
\text { such as his name, position } \\
\text { inside the company, age, } \\
\text { experience level }\end{array}$ \\
\hline Introduction & $\begin{array}{c}\text { Introduce the problem, the } \\
\text { stakeholders, then warm up } \\
\text { with the employees' feedback } \\
\text { regarding their integration } \\
\text { and other's recruitment and } \\
\text { insertion. }\end{array}$ \\
\hline Centring & $\begin{array}{c}\text { This section aims to define } \\
\text { the main problems facing } \\
\text { laureates during their first } \\
\text { missions inside the company. }\end{array}$ \\
\hline Deepening & $\begin{array}{c}\text { This section's purpose is to } \\
\text { frame the required skills and } \\
\text { knowledge, allowing newly } \\
\text { graduated students to } \\
\text { succeed. }\end{array}$ \\
\hline Conclusion & $\begin{array}{c}\text { This section is dedicated to } \\
\text { the suggestions and } \\
\text { reflections of the } \\
\text { interviewees. }\end{array}$ \\
\hline & \\
\hline &
\end{tabular}

\section{Results and Discussion}

This section will present the results related to both the survey and the interviews conducted inside an international offshoring company.

\subsection{Exploratory Analysis}

Based on the answers of $8 \%$ of employees of our targeted sample, $50 \%$ of them were men and the other $50 \%$ women, $80 \%$ of them integrate the company in 2019 .

We note that all of them were obliged to follow some mandatory training before starting with them, as $100 \%$ answered yes.

This insight on how much the company see the knowledge that the graduated engineers have not enough, making them pass multiple pieces of training ending with quizzes and evaluations before validating the integration of the member into the company. As mentioned by these engineers, most of these sessions are about security, management, agile, DevOps and others like communication, relationships and ethics.

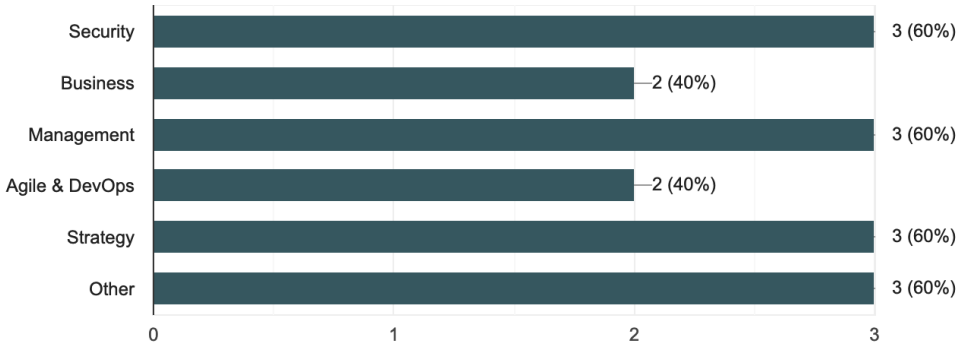

Fig. 5. The categories of training.

As shown, these trainings are acquired by most IT companies, so they must be taken seriously into consideration. Including them in the preparation of future IT engineers is vital to create a game design meeting these needs, mainly that all of this trainings are achieved on e-learning platforms, not face-to-face, as confirmed in Fig. 6 below: 


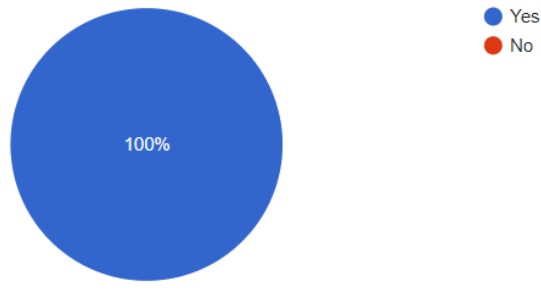

Fig. 6. The trainings were on an e-learning platform

Also found the engineer's feedback exciting as it shows the level of their satisfaction towards these sessions.

More than $40 \%$ are not satisfied with this experience and wished for another alternative as suggested many employees in the question area about their suggestions to improve this experience: "make them more interactive, the one I liked the most made their final test very interactive, and it felt like a video game, putting me in with what it seems like real situation simulated through that interactive test."

\subsection{Qualitative Analysis}

In this part, we will present our analysis of the interview questions crossing all the interviewees:

Table 3. The introductive phase of the interview.

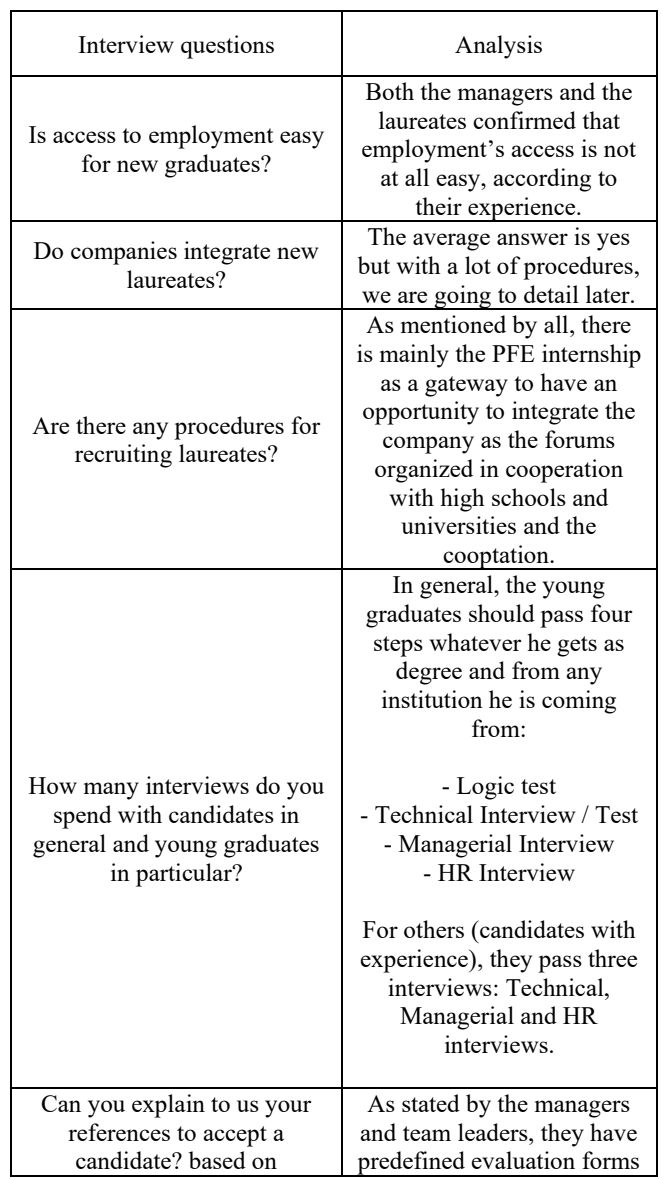




\begin{tabular}{|c|c|}
\hline predefined tests or other? & $\begin{array}{c}\text { depending on positions and } \\
\text { technologies, based on a lot } \\
\text { of rating keys and criteria } \\
\text { such as: } \\
\text { - Presentation (promptness, } \\
\text { resume, appearance ...) } \\
\text { - Education } \\
\text { - Experience (training, } \\
\text { internships...) } \\
\text { - Communication skills } \\
\text { - Problem-solving skills } \\
\text { - Stability and others... }\end{array}$ \\
\hline $\begin{array}{c}\text { Is the integration also a phase } \\
\text { of testing and validation of } \\
\text { the candidate? }\end{array}$ & $\begin{array}{l}\text { Yes, the company make a } \\
\text { three months trial period for } \\
\text { the new graduates. Even, } \\
\text { after the achievements of } \\
\text { their PFE internship (six } \\
\text { months) still, the integration } \\
\text { could be validated or } \\
\text { rejected. }\end{array}$ \\
\hline $\begin{array}{l}\text { Did you take any trainings } \\
\text { during your integration into } \\
\text { the company? Can you tell us } \\
\text { about your experience? }\end{array}$ & $\begin{array}{l}\text { All the employees took } \\
\text { trainings, and the feedback } \\
\text { on the experience of all of } \\
\text { them was not bad and } \\
\text { interesting sessions but very } \\
\text { annoying. }\end{array}$ \\
\hline $\begin{array}{c}\text { Is the training that members } \\
\text { take mandatory? }\end{array}$ & $\begin{array}{l}\text { Yes, all the trainings are } \\
\text { mandatory to pass, and they } \\
\text { all must pass the quiz } \\
\text { evaluations at the end. }\end{array}$ \\
\hline $\begin{array}{l}\text { How do you achieve these } \\
\text { trainings? }\end{array}$ & $\begin{array}{l}\text { All the members pass their } \\
\text { training on an e-learning } \\
\text { platform called SkillPort } \\
\text { belongs to SkillSoft. }\end{array}$ \\
\hline $\begin{array}{l}\text { What is the nature of the } \\
\text { training? }\end{array}$ & $\begin{array}{l}\text { The trainings vary between } \\
\text { tutoring of security, data } \\
\text { privacy, communication... }\end{array}$ \\
\hline
\end{tabular}

The first part of the interview allowed us to understand how the companies, especially this IT company procedure with newly graduated students before recruiting them, following the interviews and the trainings required. Next, we will initiate the games approach with them during the centering part to study the possibility of applying gamification or developing game adapted for their trainings.

Table 4. Centering phase of the interview.

\begin{tabular}{|c|c|}
\hline Interview questions & Analysis \\
\hline $\begin{array}{c}\text { What do you think of training in } \\
\text { the form of serious or fun } \\
\text { games? }\end{array}$ & $\begin{array}{c}\text { All agreed that any kind } \\
\text { of games when applied } \\
\text { on a training or other } \\
\text { make it fun and } \\
\text { entertainment not just a } \\
\text { requirement but it's } \\
\text { engaging and } \\
\text { motivating. }\end{array}$ \\
\hline & $\begin{array}{c}\text { Multiple examples of } \\
\text { trainings were given }\end{array}$ \\
such as: \\
$\begin{array}{c}\text { Can you give us examples of } \\
\text { trainings that could be serious } \\
\text { games within the company? }\end{array}$ & $\begin{array}{c}\text { simulation of security } \\
\text { trainings and anti- } \\
\text { corruption sessions } \\
\text { - GPDR: the general data } \\
\text { protection regulation }\end{array}$ \\
& - Ethics of the company \\
& -Agility... \\
\hline
\end{tabular}




\begin{tabular}{|c|c|}
\hline $\begin{array}{c}\text { How do you define a successful } \\
\text { or unsuccessful integration of a } \\
\text { laureate? }\end{array}$ & $\begin{array}{c}\text { According to the } \\
\text { answers collected within } \\
\text { the interview, successful } \\
\text { integration of new } \\
\text { graduates is defined by: } \\
\text { - Productivity } \\
\text { - Being operational } \\
\text { - Sense of initiative } \\
\text { - Team spirit } \\
\ldots\end{array}$ \\
\hline $\begin{array}{c}\text { In your opinion, is the } \\
\text { integration efficiency of young } \\
\text { graduates is the same as a } \\
\text { candidate with experience? }\end{array}$ & $\begin{array}{c}\text { Of course not, they find } \\
\text { the communication with } \\
\text { an experienced engineer } \\
\text { much easier as they on } \\
\text { the same page for all the } \\
\text { aspects. }\end{array}$ \\
\hline $\begin{array}{c}\text { What do you base yourself on } \\
\text { during the trial period to validate } \\
\text { or not the young graduates? }\end{array}$ & $\begin{array}{c}\text { As mentioned before } \\
\text { mainly the operational } \\
\text { productivity and } \\
\text { especially the integration } \\
\text { with teams and } \\
\text { colleagues. }\end{array}$ \\
\hline $\begin{array}{c}\text { In your experience, how many } \\
\text { students (approximately) are not } \\
\text { validated after their trial period? }\end{array}$ & $\begin{array}{c}\text { According to the } \\
\text { manager's experience, } \\
\text { nearly 10\% of students } \\
\text { don't get the job. }\end{array}$ \\
\hline
\end{tabular}

In this part of the interview, we focused on identifying the exact needs required of the students.

Table 5. Deepening phase of the interview.

\begin{tabular}{|c|c|}
\hline Interview questions & Analysis \\
\hline $\begin{array}{l}\text { Can you tell us about your } \\
\text { feedback on the academic } \\
\text { courses of young graduates or } \\
\text { with whom you have } \\
\text { collaborated? }\end{array}$ & $\begin{array}{l}\text { All agreed that any } \\
\text { games, when applied on } \\
\text { training or other make it } \\
\text { fun and entertainment, } \\
\text { not just a requirement } \\
\text { but it's engaging and } \\
\text { motivating. }\end{array}$ \\
\hline $\begin{array}{l}\text { Is the knowledge acquired by } \\
\text { young graduates in line with the } \\
\text { skills required by the company? }\end{array}$ & $\begin{array}{l}\text { The managerial layer } \\
\text { confirmed that the } \\
\text { knowledge meets the } \\
\text { knowledge needed more } \\
\text { often but not the skills; } \\
\text { otherwise, the graduated } \\
\text { engineers reported that } \\
\text { they had to self-train } \\
\text { about new technologies } \\
\text { have seen or heard of for } \\
\text { the first time inside the } \\
\text { company. }\end{array}$ \\
\hline $\begin{array}{l}\text { What do you think of the } \\
\text { professional or technical skills of } \\
\text { the young graduates? }\end{array}$ & Match the needs. \\
\hline $\begin{array}{l}\text { What do you think of the } \\
\text { transversal or soft skills of } \\
\text { young graduates? }\end{array}$ & $\begin{array}{l}\text { The central aspect where } \\
\text { most of the students } \\
\text { have problems } \\
\text { considering teamwork, } \\
\text { communication, making } \\
\text { decisions }\end{array}$ \\
\hline $\begin{array}{c}\text { What aspects of skills are often } \\
\text { lacking in these young } \\
\text { graduates? }\end{array}$ & $\begin{array}{l}\text { As cited in common by } \\
\text { all of them: } \\
\text { - Flexibility } \\
\text { - Time management } \\
\text { - Ability to work under } \\
\text { pressure }\end{array}$ \\
\hline
\end{tabular}




\begin{tabular}{|c|c|}
\hline & - Teamwork \\
& - Professional \\
& communication \\
& - Responsibility \\
& - Negotiation \\
& - Leadership \\
\hline $\begin{array}{c}\text { Training students in the } \\
\text { company's different aspects and } \\
\text { skills could help them integrate } \\
\text { easily into the professional and } \\
\text { operational activity? }\end{array}$ & $\begin{array}{c}\text { Yes, of course, the } \\
\text { company invest a lot of } \\
\text { time and resources to } \\
\text { teach the new graduates } \\
\text { some skills and training. }\end{array}$ \\
\hline
\end{tabular}

Finally, we concluded the interview with an open question:

"What are your recommendations for having a young graduate who meets the expectations of the job market?". One manager having his degree in the united states suggested, based on his experience, that we have to think about part-time jobs. Getting some exciting feedback encouraging this study to help the students pass these training or get the skills using a well-designed game, allowing them to acquire a lot of the mentioned abilities. Also, they play a primary role to prepare students for the job markets. They cover a lot of aspects too.

\section{Conclusion}

Playing games, regardless of being active, mentally stimulates us and keeps us from feeling bored or distracted, and the feeling of accomplishment is closely linked to goal achievement. Our goal to achieve is mainly easing and make the laureate's integration into professional life very successful. We started with the analysis of the literature review. Then we implemented two games to test the approach. We conducted multiple interviews and surveys to gather the main needs should our game satisfy before getting deeper to create its prototype aiming to fulfil these needs in different offshoring enterprises. The results concluded strongly supports the necessity of preparing our graduated students in areas other than technical and theoretical knowledge, and games are capable of being practical, efficient tools for teaching and considering these skills.

\section{References}

1. Sabri Zineb, Moumen Aniss, Fakhri Youssef. "Gamifying eLearning to Improve Professional Integration to Labor Market Systematic Literature Review." 2020.

2. Marfisi-Schottman, I., George, S., \& Tarpin-Bernard, F. (2010). Tools and methods for efficiently designing serious games. In, no. October. 4th European conference on game-based learning (pp. 226-234).

3. M. BenRabha, M.F. Boujmil, M. Saadoun, B. Bessaïs, Eur. Phys. J. Appl. Phys. (to be published)

4. L. T.De Luca, Propulsion physics (EDP Sciences, Les Ulis, 2009)

5. ORABI, M. (2020). Les pratiques de bien-être au travail dans les entreprises au Maroc: enseignements d'une étude de cas. Moroccan Journal of Quantitative and Qualitative Research, 2(1), 1-14. doi:https://doi.org/10.48379/IMIST.PRSM/mjqr- 